Primljen / Received: 9.9.2013. Ispravljen / Corrected: 10.1.2014. Prihvaćen / Accepted: 17.1.2014. Dostupno online / Available online: 10.3.2014.

\section{State of the art review of the stability and welding of aluminium alloy elements}

\section{Authors:}

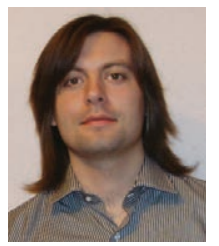

Tihomir Dokšanović, mag.ing.aedif. University J. J. Strossmayer in Osijek Faculty of Civil Engineering of Osijek tdoksanovic@gfos.hr

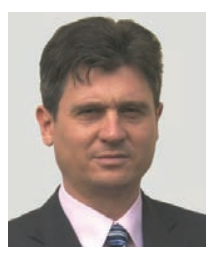

Prof. Damir Markulak, PhD. CE University J. J. Strossmayer in Osijek Faculty of Civil Engineering of Osijek markulak@gfos.hr

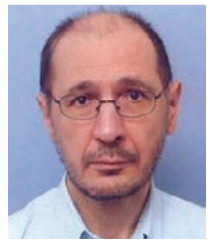

Prof. Ivica Džeba, PhD. CE University of Zagreb Faculty of Civil Engineering ivci@grad.hr

\section{Tihomir Dokšanović, Damir Markulak, Ivica Džeba}

\section{State of the art review of the stability and welding of aluminium alloy elements}

Although aluminium is a structural material that has been present on the market for a long time, its use is not in accordance with the benefits that can be achieved by its application. While it is similar to steel, there are significant differences between these materials, both in manufacturing and in physical and mechanical properties. Due to such differences, these materials exhibit distinct features in the areas of cross sectional and elements stability and welds. These areas are still an active field of research due to a large number of alloys, processing methods, and cross-sectional shapes.

Key words:
alloy, aluminium, state-of-the art review, manufacturing, joining, stability, welding

Pregledni rad

Tihomir Dokšanović, Damir Markulak, Ivica Džeba

\section{Stanje područja stabilnosti i zavarivanja elemenata od aluminijskih legura}

lako je aluminij već dugo prisutan konstrukcijski materijal, uporaba mu nije u skladu s dobrobitima koje se ostvaruju njegovom primjenom. Sličan je čeliku, no izmedu njih postoje značajne razlike kako u proizvodnji, tako i u fizikalnim i mehaničkim svojstvima. Upravo iz tih razlika proizlaze posebnosti u područjima stabilnosti dijelova poprečnih presjeka i konstrukcijskih elemenata te u područjima zavara. Ta polja još uvijek predstavljaju aktivna područja istraživanja zbog velikog broja legura, obrada i oblika poprečnih presjeka profila.

Ključne riječi:

legura, aluminij, pregled stanja, proizvodnja, spajanje, stabilnost, zavarivanje

Übersichtsarbeit

Tihomir Dokšanović, Damir Markulak, Ivica Džeba

\section{Neuester Stand zur Stabilität und Schweissung von Elementen aus Aluminiumlegierungen}

Obwohl Aluminium schon lange als Konstruktionsmaterial bekannt ist, wird es nicht den Vorteilen seiner Anwendung entsprechend eingesetzt. Auch wenn das Material mit Stahl verglichen werden kann, bestehen bedeutende Unterschiede, sowohl in der Herstellung, als auch in den physikalischen und mechanischen Eigenschaften. Folglich umfassen die Stabilität der Querschnitte oder Elemente und die Schweißflächen eine Reihe von Besonderheiten, die weiterhin einen aktiven Forschungsbereich darstellen, insbesondere aufgrund der großen Anzahl von Legierungen, Verarbeitungsmethoden und Querschnittsformen. 


\section{Introduction}

Although aluminium was discovered in its elementary state more than two hundred years ago, it started to be considered as a serious industrial material only after invention of the modern bauxite processing procedure in 1886 [1] because, until that time, the price of its production was extremely high and was comparable to the price of gold. In civil engineering practice, aluminium is used in form of alloys as its strength is insufficient in elementary state. Possible alloys, the testing of such alloys, and the influence of temperature and method of treatment on their properties, have been studied [2] since the start of the twentieth century, and the first registered use of aluminium as a construction element dates back to 1898 when it was used in form of plates to cover the dome of the St. Jacob's Church in Rome, which has remained undamaged to this day [3]. From that time onwards, its use has been continuously increasing, but this trend is still not followed in a great number of countries where design regulations have not as yet been implemented, where there is no engineering tradition in the use of aluminium alloys in structural applications, and where there is no systematic education about aluminium alloys as a possible building material.

The evidence of its high potential lies in an ever increasing number of various new structures or refurbishment projects in which it is used either as a dominant material or in combination with an another material - antenna towers, production halls, bridges, overhead line towers, large-span geodesic domes, structures in areas with extremely low temperatures, etc. [4]. In fact, the combination of a relatively high ratio of strength to self-weight, higher durability, and availability in a great number of forms, makes aluminium alloys an excellent choice for a wide variety of structural applications. Aluminium alloys mechanical properties are able to meet high standards set by steel (Table 1), but these properties do come with certain particularities. A relatively high price of aluminium often results in elements of great slenderness that are susceptible to local or global forms of stability loss and, due to the fact that the modulus of elasticity of aluminium is three times smaller compared to steel, aluminium alloy elements of the slenderness comparable to steel elements are characterised by smaller resistance to various forms of local buckling and buckling. In addition, its behaviour without a clearly defined yield strength, its production method, and its pronouncedly purpose-oriented production, often resulting in complex forms of cross-section, make the field of stability the area of significant research activity, which is highly open to new developments and perceptions. Other than the issue of stability, aluminium is prone to significant change of properties when welded, which may result in local loss of resistance capacity, or complicate loss of stability behaviour description.

As these areas are significant in the context of further research, and considering latest achievements in this area, the purpose of this paper is to provide a systematic overview of recent research in the field of structural aluminium alloys with the focus on stability issues and the effects of welding. The topicality of this purpose is additionally stressed by publication of the Technical Regulation for Aluminium Structures [5] which will make aluminium alloys, regarded as structural material, more readily available to engineers in Croatia.

\section{Manufacture of aluminium semi-products}

Unlike steel where the most common structural product manufacturing process is rolling, aluminium alloys are in most cases processed by extrusion. In fact, extrusion has become a significant metal manufacturing procedure only after the use

Table 1.Comparison of physical and mechanical properties of selected structural aluminium alloys and structural steels, according to [1, 6, 7]

\begin{tabular}{|c|c|c|c|c|c|}
\hline \multirow{2}{*}{ Property } & \multicolumn{3}{|c|}{ Aluminium alloy series } & \multicolumn{2}{|c|}{ Structural steel types } \\
\hline & $\begin{array}{c}5000 \\
\text { (Al-Mg) }\end{array}$ & $\begin{array}{c}6000 \\
\text { (Al-Mg-Si) }\end{array}$ & $\begin{array}{c}7000 \\
(\mathrm{Al}-\mathrm{Zn}-\mathrm{Mg})\end{array}$ & S $235 \mathrm{JR}$ & S 355 JR \\
\hline Density [kg/m³] & \multicolumn{3}{|c|}{2700} & \multicolumn{2}{|c|}{7850} \\
\hline Modulus of elasticity [N/mm²] & \multicolumn{3}{|c|}{70000} & \multicolumn{2}{|c|}{210000} \\
\hline Shear modulus $\left[\mathrm{N} / \mathrm{mm}^{2}\right]$ & \multicolumn{3}{|c|}{26000} & \multicolumn{2}{|c|}{81000} \\
\hline Poisson's ratio & \multicolumn{3}{|c|}{0,33} & \multicolumn{2}{|c|}{0,30} \\
\hline Coefficient of linear thermal expansion $\left[1 /{ }^{\circ} \mathrm{C}\right]$ & \multicolumn{3}{|c|}{$24 \times 10-6$} & \multicolumn{2}{|c|}{$12 \times 10-6$} \\
\hline Melting temperature $\left[{ }^{\circ} \mathrm{C}\right]$ & \multicolumn{3}{|c|}{660} & \multicolumn{2}{|c|}{1500} \\
\hline Yield strength [N/mm²] & $\approx 160$ & $\approx 260$ & $\approx 360$ & 235 & 355 \\
\hline Tensile strength [N/mm²] & $\approx 280$ & $\approx 320$ & $\approx 410$ & 360 & 510 \\
\hline Elongation at failure [\%] & \multicolumn{3}{|c|}{$\approx 10$} & \multicolumn{2}{|c|}{$\approx 25$} \\
\hline Tensile strength to yield strength ratio $\left[\mathrm{N} / \mathrm{mm}^{2} / \mathrm{N} / \mathrm{mm}^{2}\right]$ & 1,75 & 1,23 & 1,14 & 1,53 & 1,44 \\
\hline Tensile strength to weight ratio $\left[\mathrm{N} / \mathrm{mm}^{2} / \mathrm{kN} / \mathrm{m}^{3}\right]$ & 104 & 119 & 152 & 46 & 65 \\
\hline
\end{tabular}


of aluminium started. It is the procedure in which aluminium alloy ingots, previously heated to the extrusion temperature which is usually $500{ }^{\circ} \mathrm{C}[1]$, are rammed through the steel die which has an opening of desired shape, as shown in Figure 1. After extrusion, the section is usually extended so as to correct imperfections related to deviation from the straight line, and the extrusion procedure itself induces very small residual stresses which can be neglected for practical purposes, regardless of the way in which the heat treatment was made [8].

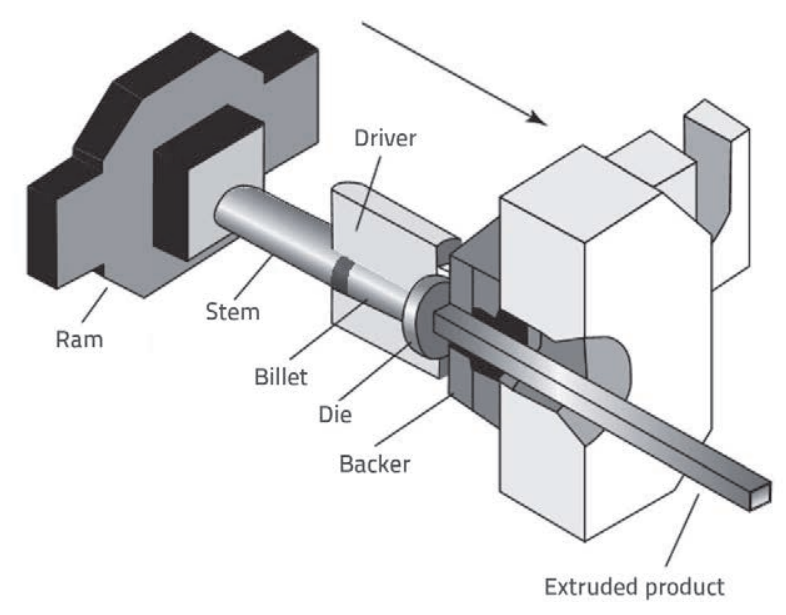

Figure 1. Section manufacturing by extrusion [9]

The manufacturing price of a new type of an element's cross section is negligible compared to steel, and the time of work interruption to change the mould is also negligible compared to the change of rolling procedure in steel mills [1]. For that reason, it is common practice to design special purposeoriented cross sections, so that they can be as economical as possible for their future use, i.e. so that they can be adjusted to particular static and functional requirements. Some typical cross sections that can be obtained by extrusion are presented in Figure 2. Quantities needed for economical production of a aluminium cross section vary from 200 to
$3000 \mathrm{~kg}$ [10] depending of the size of cross section, and the quantity needed for economical production of elements made of usual steel alloys is $10000 \mathrm{~kg}$. However, if an unusual alloy is needed, then as many as 30000 to $50000 \mathrm{~kg}$ have to be ordered [10]. It is therefore quite clear why 90 percent [10] of aluminium sections manufactured are shaped for a particular purpose, and this high level of specialisation results in low rate of storage of aluminium elements.
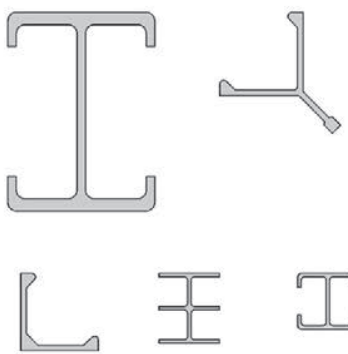
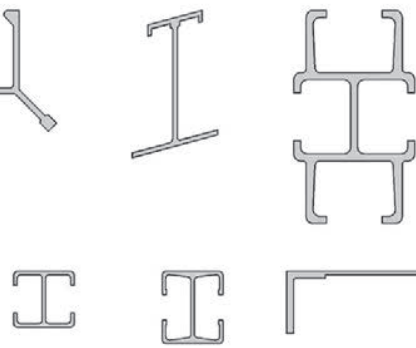

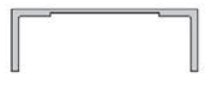

Figure 2. Some possible cross-sectional forms obtained by extrusion [6]

\section{Stability}

In addition to having a lower modulus of elasticity than steel, aluminium alloys are also characterized by elastoplastic behaviour (even before the $0.2 \%$ strain limit) without a clearly defined yield point, and by pronounced strain-hardening, which implies that the loss of stability occurs mostly in nonlinear range and that it is therefore harder to analytically describe [11]. As aluminium alloy elements are mostly formed by extrusion after which the deviation from straightness is corrected through elongation, possible occurrence of the Bauschinger effect should be considered [12]. A common feature of steel and aluminium elements is the influence of geometrical imperfection (deviation from straightness), residual stresses, restraint conditions, and the type of load, on stability. As aluminium sections are most often manufactured for a particular purpose, the complexity of shape results in

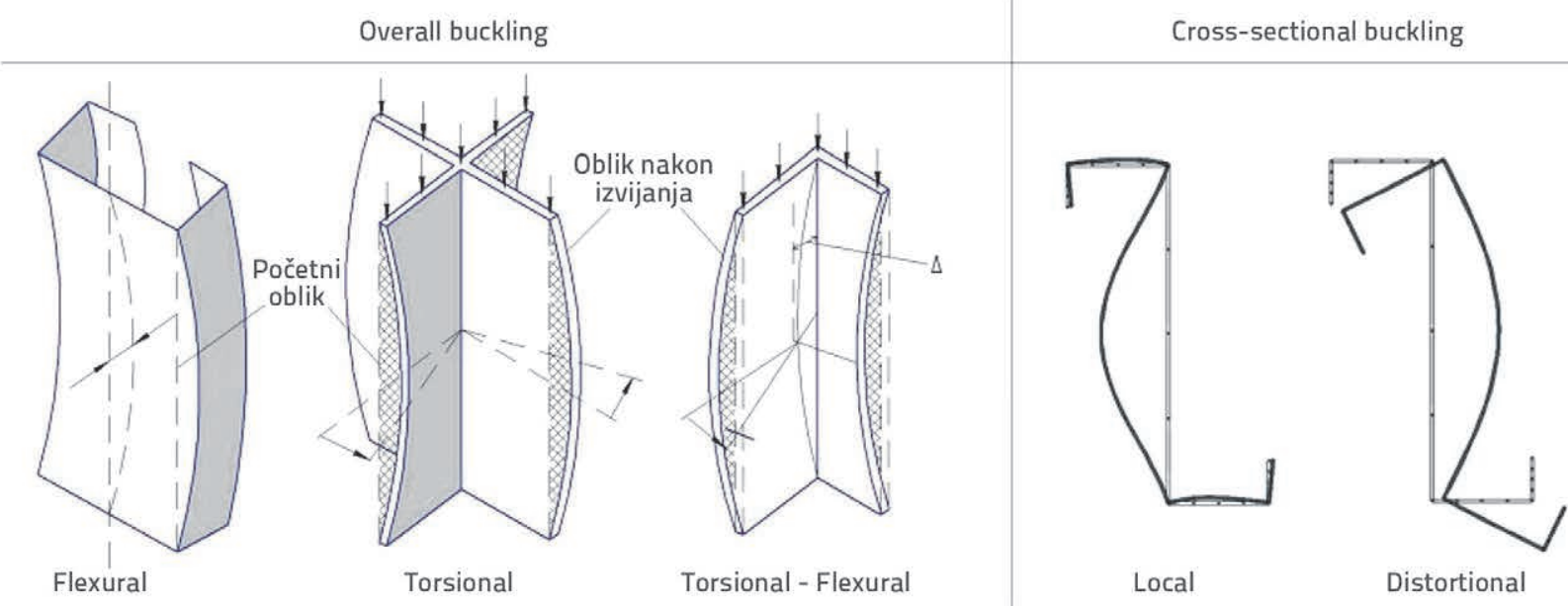

Figure 3. Types of buckling and local buckling of aluminium alloy elements [13] 
various interactions that can also be identified in steel coldformed members, as shown in Figure 3.

\subsection{Local buckling}

In order to attain resistance reserves of elements, it is first of all necessary to ensure stability at the level of cross section, and hence avoid local and distortional buckling. If this form of stability loss is possible, then it must be adequately taken into account in the design procedure. In modern technical regulations and standards, possible local buckling of slender sections is taken into account through classification according to rotation capacity, by reducing the cross section to an effective area, which is similar to the principle presented in HRN EN 1993-1-3 for cold-formed elements [14], with adjustments needed to provide for specific features of aluminium as a material. These adjustments include differences in local buckling of steel and aluminium plates as confirmed by research conducted by Jombock and Clark in 1968 [15], who proposed local buckling curves for aluminium alloy plates depending on temper, and by Dwight and Mofflin in 1982 [16], who proposed three curves depending on whether it is an external or internal element, and whether it is a welded or unwelded element. These curves are presented in Figure 4 where the curve $A$ is relevant for unwelded external elements; curve B for unwelded internal elements and welded external elements; and curve $\mathrm{C}$ for welded internal elements.

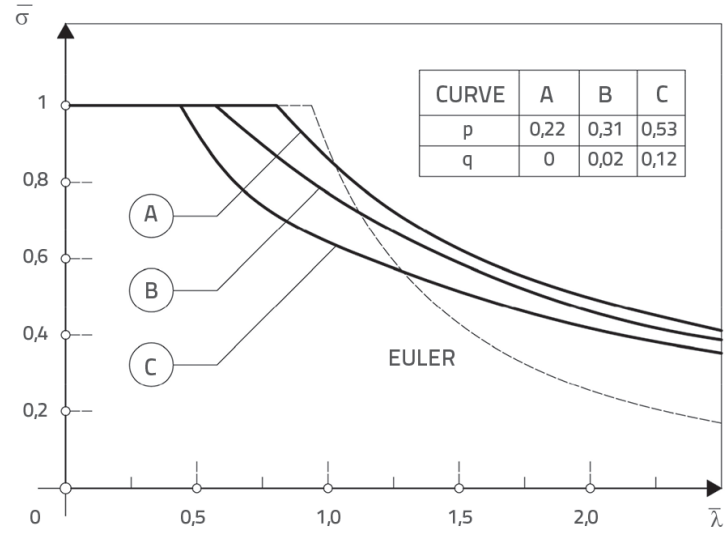

Figure 4. Local buckling curves according to Dwight and Mofflin [17]

One of significant contributions to the selection and improvement of methods for effective area calculation, as made in the scope of creation of the Eurocode for aluminium structures, is the parametric analysis conducted by Landolfo and Mazzolani [17] which was used to apply various calculation methods to a set of cross sections (boxshaped, C and omega, of various height to width ratios) using design criterias available at that time. The influence of these methods on the prediction of resistance was compared, and differences between individual methods were established. In addition to this analysis, an emphasis should also be placed on the numerical and experimental research conducted by Hopperstad, Langseth and Hanssen $[18,19]$ which provided some new information about the influence of tempers on the local buckling of square thin-walled tubular sections made of aluminium alloys from the series 6000. Mazzolani and Piluso [20] described steps of the semi-empirical method for estimation of rotation capacity of aluminium alloy elements subjected to nonuniform bending. They also expanded methods available at that time for estimation of rotation capacity of steel members, and presented preliminary results of experimental research of local buckling of aluminium alloy EN AW-6060-T6 cross sections. However, these research projects, actually aimed at preparing the basis for the European regulation on aluminium structures, comprised only a limited number of alloys, alloy tempers, cross-sectional types and height to width ratios of even simple cross-sectional shapes.
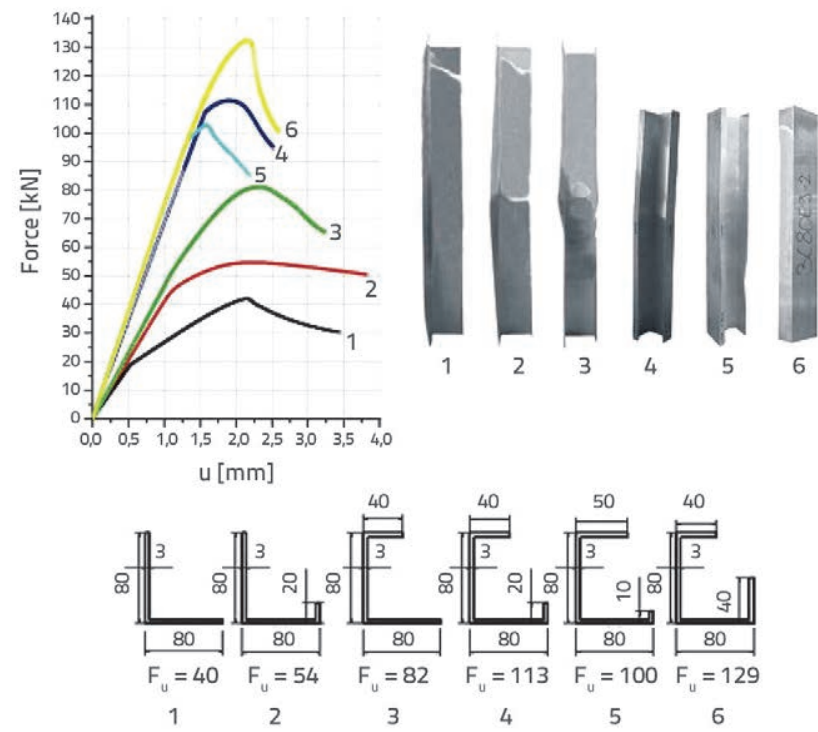

Figure 5. Test results for samples subjected to compression, with gradual increase in complexity of cross sections [13]

Subsequent research was conducted to study distortional buckling and to additionally expand studies related to local buckling in the context of complex cross sectional forms, with a greater number of different alloys and tempers, and also with the study of influence of various forms of strengthening on local-buckling. The first of these extensive studies in which experimental and numerical methods were used to study a considerable number of simple and complex cross sections was presented by Mennink, Soetens and Snijder [21, 22]. The total of 78 samples, 40 of complex shape, were studied in this research, and a calculation model for determining resistance to local buckling was developed. With such a model, the cross section resistance was successfully established in such a way that the ratio of experimentally determined load capacity and the resistance predicted by calculation model amounted to $97 \%$ on an average, with a small standard deviation. In the scope of recommendations given in the paper, it is indicated that the 
Table 2. Overview of significant experimental research relating to local buckling as conducted in the past decade

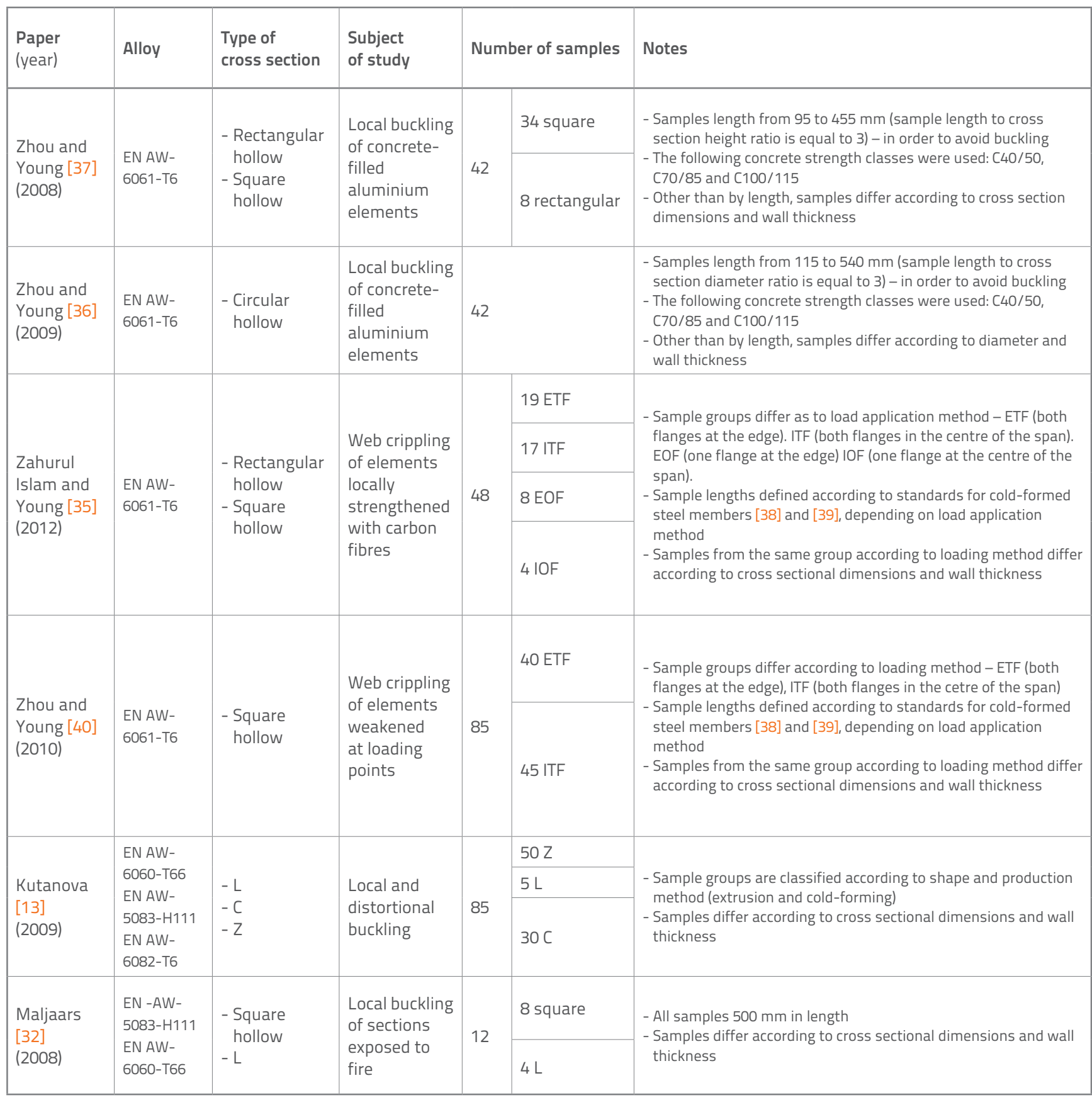

number of samples and the number of sample types should be extended, which was partly realized through subsequent research conducted by Kutanova, Peköz and Soetens [13, 23]. They tested the total of 85 samples in order to study interaction between the distortional and local buckling. Z-, L- and C-shaped sections were tested, and their lengths and cross-sectional dimensions were varied, while the complexity was gradually increased, cf. Figure 5. In addition, the Mennink's calculation model for the prediction of local buckling was verified in the scope of this research, and was additionally confirmed through realization of the model. In recommendations given in these papers, it is indicated that the cross-sectional instability was studied on relatively simple crosssections, which is why the concepts developed should additional be confirmed on more complex forms.

In their paper, De Matteis, Landolfo, Manganiello and Mazzolani [24] present results of an extensive numerical research focusing on estimation of non-elastic behaviour of I-shaped beams made of aluminium alloys EN AW-6082-T4 and EN AW-6082-T6, subjected to nonuniform bending. This research has confirmed the significance of material strain-hardening which, together with local slenderness of compression elements, exerts a significant influence on the rotation capacity of cross sections. The research 
also demonstrates that the guidelines for classification of cross sections, as given at the time in the ENV Eurocode for aluminium structures, were not sufficiently accurate and that they had to be improved. In addition, some new limits were proposed for the classification of external compression elements. In recommendations for further research, it was indicated that the focus should be placed on the study of influence of web buckling and lateral torsional buckling on the rotation capacity of cross sections, as these effects have not previously been considered. Additional research relating to the latest edition of Eurocodes and local buckling was conducted by Mazzolani and Mandara [25], Manganiello, De Matteis and Landolfo [26], and Mazzolani, Mandara and Di Lauro [27, 28, 29]. They focused on the influence of geometrical and structural imperfections on local buckling, determination of rotation capacity of elements, and confirmation of differences with respect to steel elements. Recent studies such as the one conducted by Qilin, Hailin and Yage [30] place further accent on improvement of existing calculation methods for determination of effective cross section area. The study [30] shows that restraint effects have a significant influence on the load capacity of box and channel sections, and that the proposed calculation method provides results that are sufficiently reliable for the majority of cases under study.

As aluminium is relatively sensitive to fire action, der Meulen, Maljaars and Soetens [31, 32] propose criteria for classification of cross sections in fire conditions, i.e. it was concluded that allowable rotation capacities of cross sections should be changed when fire resistance is calculated. In addition, their papers provide $\mathrm{n}$ exponents for Ramberg-Osgood equation for two series (5000 and 6000) of alloys as related to the change in temperature.

With regard to the sensitivity of aluminium alloy elements to stability problems, several authors including Hanssen, Hopperstad and Langseth [33] have studied the possibility of strengthening such elements by filling the sections with foam. Others proposed gluing carbon-fibre strengthened polymers onto internal or external sides of square and rectangular hollow sections at load application points, as can be seen in the paper presented by Wu, Zhao and Duan [34] and by Zahurul Islam and Young [35]. In addition, Zhou and Young [36, 37] conducted a research on the strengthening of square, rectangular and circular hollow sections by filling hollow space within such sections with concrete, cf. Figure 6.
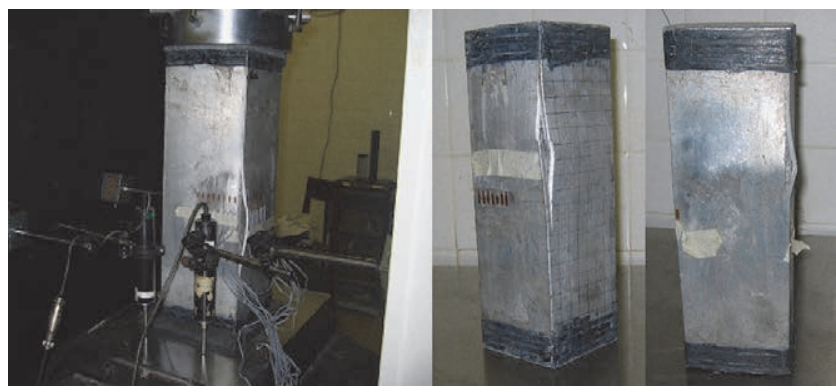

Figure 6. Testing (left) and failure mode (right) of hollow square aluminium sections filled with concrete [37]
A summary of recent experimental research related to the field of local buckling is presented in Table 2 .

\subsection{Buckling}

Current research of global forms of stability loss of aluminium alloy elements is reduced to the analysis of regularly shaped cross sections, mostly bi-symmetrical and closed. Thus circular hollow aluminium sections were studied by a number of researchers: Hill, Hartmann and Clark [41] presented already in 1956 the study of 9 circular hollow sections; Klöppel and Bärsch [42] summarized results obtained by testing 48 elements subjected to compression and bending; Mazzolani [43], 1994, and Galambos [44], 1998, summarized previous studies of aluminium elements subjected to bending and compression. In the period after 2000, studies related to global forms of stability loss have mostly been conducted in China. Zhu and Young $[45,46]$ focused on buckling and lateral torsional buckling of circular hollow aluminium sections and tested the total of 47 samples, out of which 33 were subjected to compression, 2 to bending, and 12 to bending and compression, cf. Figure 7. In addition to circular sections, Zhu and Young [8] also tested the total of 36 rectangular and square hollow aluminium elements subjected to compression, cf. Figure 7. As to other types of doubly symmetrical sections, according to [47], Wu and Zhang [48] tested lateral torsional buckling of $\mathrm{H}$ sections made of aluminium alloys and developed an expression for stability coefficient; Zhang and Zhang $[49,50]$ conducted numerical and experimental testing of H sections; Guo, Shen, Li, Su and Yao [51] derived
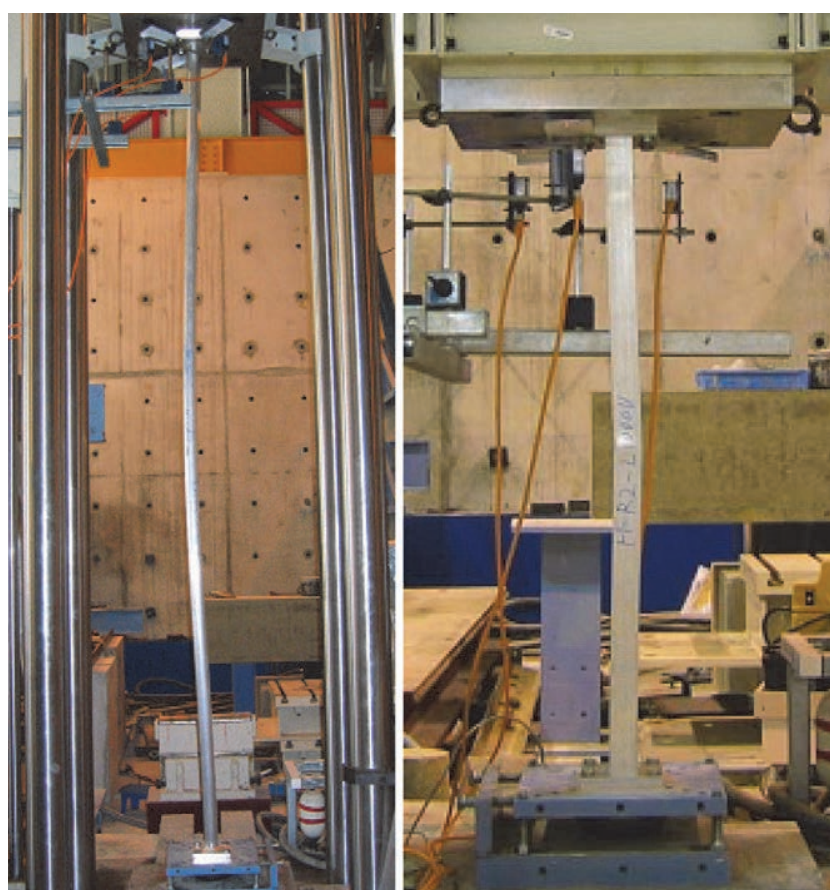

Figure 7. Compression of aluminium elements of circular (left) and square (right) hollow cross section $[8,46]$ 
an expression for the total coefficient of stability with regard to lateral torsional buckling, based on testing conducted on $\mathrm{T}$ - and $\mathrm{H}$-shaped aluminium sections. Wang, Yuan, Shi and Cheng [47] studied behaviour of $40 \mathrm{H}$-sections exposed to lateral torsional buckling. Elements with complex forms of cross section were not tested and, out of tests made on elements with singly symmetric sections, it is important to mention the study of buckling and lateral torsional buckling of T profiles conducted by Edlund [52]. He tested the total of 65 samples and, during the analysis of results and comparison with standards, he established that most standards were intended primarily for doubly symmetric $\mathrm{I} / \mathrm{H}$ sections and for circular, rectangular and square hollow sections, which is surprising as structural elements made of aluminium alloys are mostly manufactured by the extrusion method and so nonsymmetrical aluminium alloy sections are more popular than such steel sections. Even in case of sections for which standards have been adjusted, such as the relatively well studied circular hollow sections, Zhu and Young [45, 46, 53] claim that current standards are relatively conservative, and state that this inter alia includes standards from the series HRN EN 1999. This conclusion is not unusual as the Eurocode for aluminium structures approaches the stability loss issue in generally the same way as this issue is dealt with in HRN EN 1993. In fact, due to lack of experimental results, specific features of aluminium are incorporated in

Table 3. Overview of significant stability-related experimental research conducted over the past 10 years

\begin{tabular}{|c|c|c|c|c|c|c|}
\hline $\begin{array}{l}\text { Paper } \\
\text { (year) }\end{array}$ & Alloy & $\begin{array}{l}\text { Type of } \\
\text { cross } \\
\text { section }\end{array}$ & $\begin{array}{l}\text { Subject } \\
\text { of study }\end{array}$ & \multicolumn{2}{|c|}{ Number of samples } & Notes \\
\hline $\begin{array}{l}\text { Zhu and } \\
\text { Young [46] } \\
\text { (2006) }\end{array}$ & $\begin{array}{l}\text { EN AW-6063-T5 } \\
\text { EN AW-6061-T6 }\end{array}$ & $\begin{array}{l}\text { - Circular } \\
\text { hollow }\end{array}$ & $\begin{array}{l}\text { Buckling and } \\
\text { influence of } \\
\text { welding }\end{array}$ & 29 & 8 unwelded & $\begin{array}{l}\text { - Samples fixed at their ends, differ from one another by the } \\
\text { type of connection - with transverse welds or without them } \\
\text { - Samples } 300 \text { to } 3000 \mathrm{~mm} \text { in length } \\
\text { - All samples are } 50 \mathrm{~mm} \text { in diameter, and they differ by wall } \\
\text { thickness } \\
\text { - Test results are compared with results of the US, Australian } \\
\text { and European standards for aluminium structures }\end{array}$ \\
\hline $\begin{array}{l}\text { Zhu and } \\
\text { Young [8] } \\
\text { (2006) }\end{array}$ & $\begin{array}{l}\text { EN AW-6063-T5 } \\
\text { EN AW-6061-T6 }\end{array}$ & $\begin{array}{l}\text { - Rectangular } \\
\text { hollow } \\
\text { - Square } \\
\text { hollow }\end{array}$ & $\begin{array}{l}\text { Buckling and } \\
\text { influence of } \\
\text { welding }\end{array}$ & 36 & 25 bending & $\begin{array}{l}\text { - Samples fixed at their ends, differ from one another by the } \\
\text { type of connection - with transverse welds or without them } \\
\text { - Samples } 300 \text { to } 3000 \mathrm{~mm} \text { in length } \\
\text { - Other than by length, samples differ according to cross } \\
\text { sectional dimensions and wall thickness } \\
\text { - Test results are compared with results of the US, Australian } \\
\text { and European standards for aluminium structures, and } \\
\text { appropriate reliability indices are indicated }\end{array}$ \\
\hline $\begin{array}{l}\text { Zhu i Young } \\
{[45]} \\
(2006)\end{array}$ & EN AW-6061-T6 & $\begin{array}{l}\text { - Circular } \\
\text { hollow }\end{array}$ & $\begin{array}{l}\text { Buckling and } \\
\text { interaction } \\
\text { between } \\
\text { bending and } \\
\text { compression }\end{array}$ & 19 & $\begin{array}{l}12 \text { bending } \\
\text { and } \\
\text { compression }\end{array}$ & $\begin{array}{l}\text { - Samples fixed at their ends } \\
\text { - Samples } 500 \text { to } 1500 \mathrm{~mm} \text { in length } \\
\text { - All samples are } 50 \mathrm{~mm} \text { in diameter, and they differ according } \\
\text { to wall thickness } \\
\text { - Samples are subjected to axial compression and, in case } \\
\text { simultaneous influence of compression and bending is } \\
\text { analyzed, the compression force is applied with a certain } \\
\text { eccentricity }\end{array}$ \\
\hline $\begin{array}{l}\text { Wang, } \\
\text { Yuan, Shi } \\
\text { and Cheng } \\
{[47]} \\
(2012)\end{array}$ & $\begin{array}{l}\text { EN AW-6063-T5 } \\
\text { EN AW-6061-T6 }\end{array}$ & $-\mathrm{H}$ & $\begin{array}{l}\text { Lateral } \\
\text { torsional } \\
\text { buckling }\end{array}$ & \multicolumn{2}{|l|}{40} & $\begin{array}{l}\text { - Sample ends rigidly restrained } \\
\text { - Lateral unbraced sample length from } 350 \text { to } 1800 \mathrm{~mm} \\
\text { (6061-T6) and from } 450 \text { to } 2200 \mathrm{~mm} \text { (6063-T5) } \\
\text { - All samples have the same web height ( } 92 \mathrm{~mm} \text { ), the same } \\
\text { web thickness ( } 3 \mathrm{~mm}) \text {, flange thickness ( } 4 \mathrm{~mm} \text { ), and they } \\
\text { differ according to width of compression and tensile flanges }\end{array}$ \\
\hline $\begin{array}{l}\text { Wu and } \\
\text { Zhang [48] } \\
\text { (2006) }\end{array}$ & EN AW-6061-T6 & $-\mathrm{H}$ & $\begin{array}{l}\text { Lateral } \\
\text { torsional } \\
\text { buckling }\end{array}$ & \multicolumn{2}{|l|}{10} & $\begin{array}{l}\text { - Sample ends are simply supported } \\
\text { - Sample length varies from } 1000 \text { to } 1800 \mathrm{~mm}\end{array}$ \\
\hline $\begin{array}{l}\text { Edlund [52] } \\
\text { (2000) }\end{array}$ & EN AW-6082-T6 & $-\mathrm{T}$ & $\begin{array}{l}\text { Flexural } \\
\text { and lateral } \\
\text { torsional } \\
\text { buckling, and } \\
\text { influence of } \\
\text { welding }\end{array}$ & 65 & 39 unwelded & $\begin{array}{l}\text { - All unwelded and } 34 \text { welded samples are simply supported } \\
\text { during the testing, and the remaining } 5 \text { samples are rigidly } \\
\text { restrained at the ends } \\
\text { - lateral unrestrained sample lengths amount to 500, } 1020 \\
\text { and } 1540 \mathrm{~mm}\end{array}$ \\
\hline
\end{tabular}


the design methodology in a rather conservative manner. Resistance values at the level of cross section are reduced by the from HRN EN 1993 known reduction factor, but are also additionally changed by the factor which in case of buckling includes weakening due to welding and, in case of lateral torsional buckling, weakening due to welding and possible local buckling of the compression zone.

Despite a considerable number of papers published about this topis, there is still ample room for further research. Due to lack of data about the testing of aluminium I/H sections subjected to bending only, nonsymmetrical and singly-symmetrical cross sections have not been sufficiently studied. The influence of constraints must be studied in further detail, standards should be improved in the area of non-symmetrical cross sections and, generally, the data base of test results relating to global forms of stability loss must be extended because of statistical parameters that are needed for probabilistic analysis of the reliability of such elements. In the conclusion of their paper, Cheng, Shi and Wang [12] specifically state that the global stability of thin-walled aluminium beams should be studied in more detail.

\section{Welding}

Aluminium is welded according to principles similar to those aplicable for steel. However, welding methods are somewhat different due to specific properties of aluminium as specified in Table 4, but the use is made of welding advantages that are also valid for steel. For aluminium structures, the most significant welding procedures are [54] gas welding (autogenous welding), metallic arc welding, tungsten inert gas welding (TIG), metal inert gas welding (MIG), laser welding, and friction welding (FS).

Out of the mentioned methods, welding procedures TIG (Tungsten Inert Gas) and MIG (Metal Inert Gas) have enabled great advances in the use of welding in aluminium structures and, according to Soetens and van Hove [54], these are the most frequently used welding methods. It is important to note that, during welding, aluminium properties change in the zone immediately next to the weld. This change occurs due to the introduction of temperature into the base material which annuls the treatment certain alloys are subjected to during their processing. This negative influence of welding is still being studied, as can be seen in Table 3 .

Table 4. Differences between steel and aluminium that negatively affect weldability of aluminium [55]

\begin{tabular}{|l|l|}
\hline Difference of properties & Consequence \\
\hline $\begin{array}{l}\text { Coefficient of thermal } \\
\text { expansion of aluminium is } \\
\text { twice that of steel }\end{array}$ & $\begin{array}{l}\text { Greater possibility of } \\
\text { unacceptable distortion during } \\
\text { welding }\end{array}$ \\
\hline $\begin{array}{l}\text { Coefficient of thermal } \\
\text { conductivity of aluminium is six } \\
\text { times that of steel }\end{array}$ & $\begin{array}{l}\text { The heat source for welding } \\
\text { aluminium must be far more } \\
\text { intense and concentrated }\end{array}$ \\
\hline $\begin{array}{l}\text { Specific heat of aluminium is } \\
\text { twice that of steel }\end{array}$ & $\begin{array}{l}\text { Longer exposure to heat is } \\
\text { needed to attain the desired } \\
\text { temperature }\end{array}$ \\
\hline $\begin{array}{l}\text { Electric conductivity of } \\
\text { aluminium is six times that of } \\
\text { steel }\end{array}$ & $\begin{array}{l}\text { Reduced applicability of } \\
\text { resistance spot welding, which } \\
\text { is based on heat generated } \\
\text { through electrical resistance }\end{array}$ \\
\hline $\begin{array}{l}\text { Unlike steel, aluminium does } \\
\text { not change colour with an } \\
\text { increase in temperature }\end{array}$ & $\begin{array}{l}\text { This makes it difficult for welder } \\
\text { to estimate when the material } \\
\text { will melt }\end{array}$ \\
\hline
\end{tabular}

According to Kissell and Ferry [56], this is the reason why mechanical joints are used more often in aluminium structures than in steel ones, even when we take into account the fact that there are less qualified welders of aluminium compared to steel welders. This influence of welding on the parent material is considered in all modern standards, and the zone affected by heat created by welding is called the zone of heat influence (or ZUT in Croatian) according to Androić, Dujmović and Džeba [7], as based on the English name heat affected zone (HAZ). According to American standard AA [57], this zone is situated one inch $(25.4 \mathrm{~mm})$ to the lef and right of the weld and, according to HRN EN 1999-1-1 [58], the extent of this zone depends on the welding method (TIG or MIG), element thickness, alloy, and temper. It should be noted that it spreads in all directions from the weld - as shown in Figures 8 and 9 for various alloys and treatments. It can be seen in Figure 8
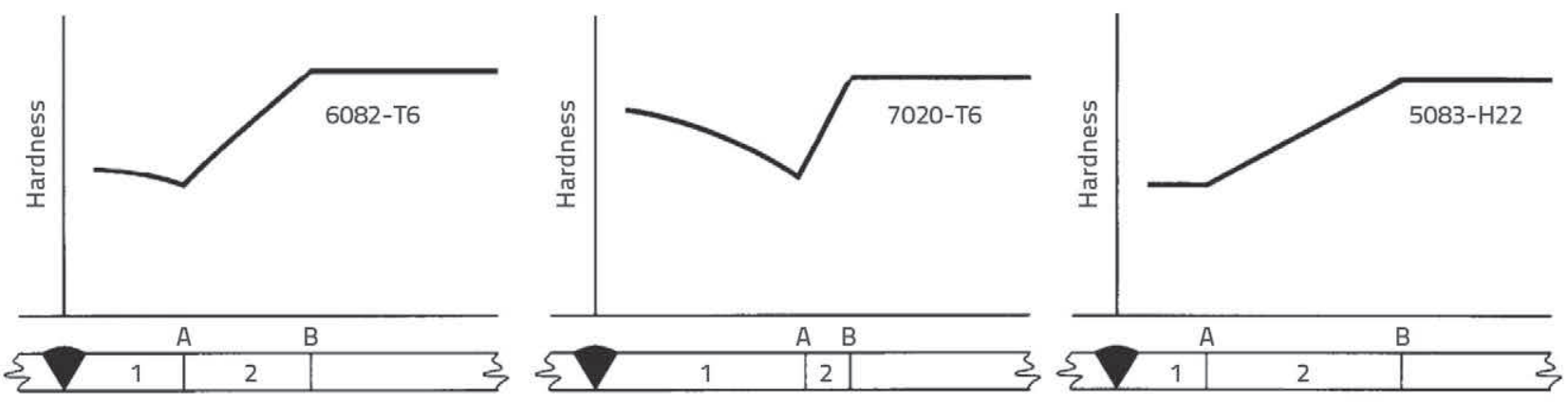

Figure 8. Typical hardness diagrams in HAZ for heat-treated (6082-T6 i 7020-T6) and work-hardened (5083-H22) alloys [1] 
that the influence of welding varies depending on temper and that the HAZ can be divided into two areas. In area 1, in case of heat-treated alloys, the metal reaches the solution treatment temperature and is able to re-age on cooling so its properties are partly restored, while in area 2 this temperature is not reached but the welding influence reduces with the increase of distance from the weld, and so the properties of the parent material are valid in point $\mathrm{B}$. In case of work-hardened alloys in area 1, the hardness is uniform and it corresponds to the alloy properties in annealed condition, while the area 2 is similar to that of heat-treated alloys. The hardness is at a minimum at the boundary between these two areas, in point A. For the aluminium alloy series 6000 , which is significant because it is used for structural purposes, the heat created by welding can locally reduce strength by almost $50 \%$ [8]. This reduction in strength is taken into account in HRN EN 1999-1-1 [58] by reduction of cross sectional area to effective area, or by reduction of strength through factors that are tabularly prescribed depending on the type of alloy, condition, and welding method (TIG or MIG). It should be noted that it is stated in the standard that the value of the reduction factor for HAZ for alloys and conditions not comprised by the standard must be determined by testing. The standard also mentions the possibility of deviation of reduction factor for $\mathrm{HAZ}$ of prescribed alloys due to possible small differences in chemical composition of the same alloy depending on the manufacturer.

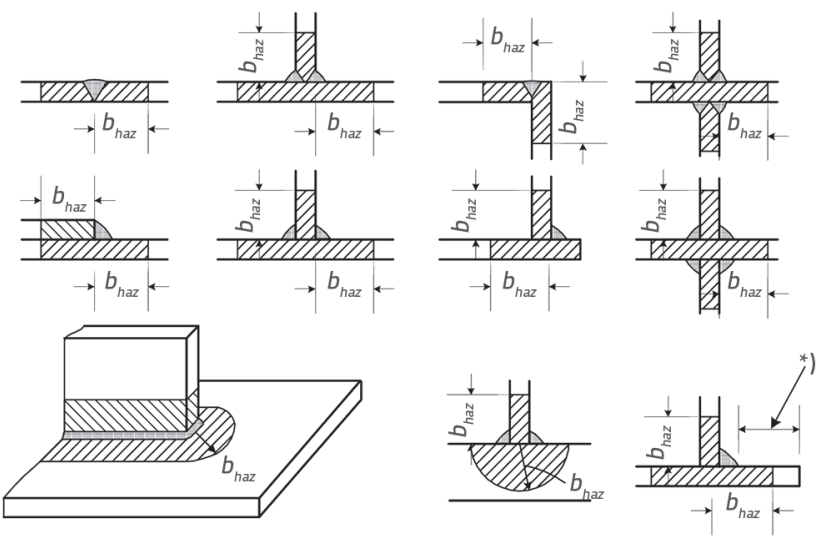

Figure 9. Extent of the heat affected zone according to HRN EN 19991-1 [58] (*if the distance is less than $3 b_{H A Z}$ it should be assumed that the HAZ extends to the full width of outstand)

The influence of welding is still the subject of a considerable number of experimental and numerical investigations [59-
64] (Table 3) because of its effect on the stability and some favourable properties. This influence is additionally studied $[65,66]$ with the introduction of new welding methods such as friction stir welding (FS - friction stir), which has a similar effect on the base material. With friction stir welding the structure of the weld is somewhat different but the HAZ exists, as shown in Figure 10, so the problems related to this form of welding are similar to those encountered in case of MIG and TIG methods.

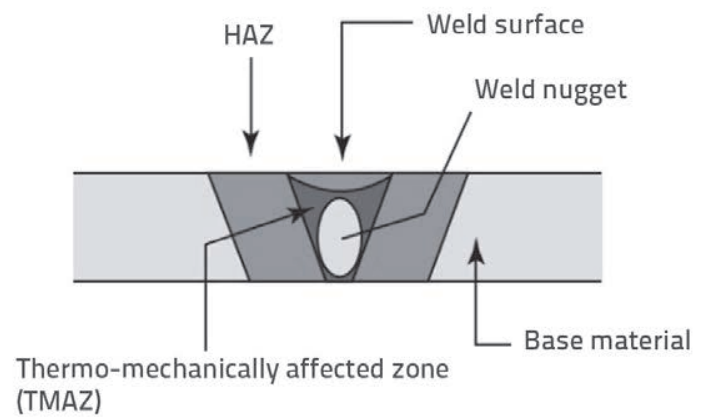

Figure 10. Weld obtained by FS welding method [9]

\section{Conclusion}

Although aluminium has been available as a construction material for quite some time now, current levels of its utilisation do not reflect benefits that can be obtained through its use. Despite the fact that aluminium is similar to steel, significant differences between these two materials exist in the manufacturing method, and also in their physical and mechanical properties. It is precisely this difference in properties, and also specific features of aluminium (localbuckling, buckling, lateral torsional buckling, and weld resistance), that have been the subject of numerous studies. Although past decades have been consecrated to the analysis of behaviour of extruded and welded aluminium members through theoretical and experimental research projects, which constitute the foundation of a modern standardisation procedure, there is still ample room for improvements due to a great number of tempers, originality of cross sections, and the number of alloys. This is also evidenced by recommendations formulated in the studies of aluminium alloys in the context of stability, where it is stated that research should be extended to more complex cross sections, and to the study of the influence of welding on stability. It can also be observed that not many papers have been written on lateral torsional stability, even in case of symmetrical cross sections. 


\section{REFERENCES}

[1] Dwight, J.: Aluminium Design and Construction, Routledge, New York City, New York, USA, 1999.

[2] Grard, C.: Aluminium and its alloys, Constable \& Company Itd., London, England, UK, 1920.

[3] European Aluminium Association (EAA): Aluminium in Building and Construction, EAA, Brussels, Belgium, 2010

[4] Mazzolani, F. M.: Structural Applications of Aluminium in Civil Engineering, Structural engineering international, 16 (2006) 4, pp. 280-285

[5] Tehnički propis za aluminijske konstrukcije. Narodne novine br. 80/2013.

[6] Buđevac, D., Marković, Z., Bogavac, D. \& Tošić, D.: Konstrukcije od aluminijskih legura (5), Metalne konstrukcije - osnove proračuna $i$ konstruisanja, Faculty of Civil Engineering of the University in Belgrade, Belgrade, Serbia, 1999.

[7] Androić, B., Dujmović, D. \& Džeba, l.: Konstrukcije iz aluminijskih legura (15), Metalne konstrukcije 1, Institut gradevinarstva Hrvatske, Zagreb, Croatia, 509-528, 1994.

[8] Zhu, J.-H. \& Young, B.: Aluminum alloy tubular columns-Part I: Finite element modeling and test verification, Thin-Walled Structures, 44 (2006) 9, pp. 961-968

[9] Müller, U.: Introduction to Structural Aluminum Design, Whittles Publishing, Dunbeath, Scotland, UK, 2011.

[10] Gitter, R.: Design of Aluminium structures: Selection of Structural Alloys, EUROCODES - Background and Applications, Brussels, Belgium, 2008.

[11] Gonçalves, R. \& Camotim, D.: GBT local and global buckling analysis of aluminium and stainless steel columns, Computers \& Structures, 82 (2004) 17-19, pp. 1473-1484

[12] Cheng, M., Shi, Y. \& Wang, Y.: Analysis of lateral stability of I-section aluminum beams, Science in China Series $E$ : Technological Sciences, 49 (2006) 6, pp. 742-751

[13] Kutanova, N.: Cross-sectional instability of aluminium extrusions with complex cross-sectional shapes (Doctoral thesis), University of Technology, Eindhoven, The Netherlands, 2009.

[14] European Committee for Standardization (CEN): EN 1993-1-3, Eurocode 3: Design of steel structures - Part 1-3: General rules - Supplementary rules for cold-formed members and sheeting, CEN, Brussels, Belgium, 2006.

[15] Jombock, J. R. \& Clark, J. W.: Bending strength of aluminum formed sheet members, Journal of the Structural Division, ASCE, 94 (1968) ST2, pp.

[16] Dwight, J. B. \& Mofflin, D. D.: Local buckling of aluminium: Preliminary proposal, ECCS Committee T2 Document, (1982) pp.

[17] Landolfo, R. \& Mazzolani, F. M.: Different approaches in the design of slender aluminium alloy sections, Thin-Walled Structures, 27 (1997) 1, pp. 85-102

[18] Hopperstad, O. S., Langseth, M. \& Hanssen, L.: Ultimate compressive strength of plate elements in aluminium: Correlation of finite element analyses and tests, Thin-Walled Structures, 29 (1997) 1-4, pp. 31-46

[19] Langseth, M. \& Hopperstad, O. S.: Local buckling of square thinwalled Aluminium extrusions, Thin-Walled Structures, 27 (1997) 1, pp. 117-126

[20] Mazzolani, F. M. \& Piluso, V.: Prediction of the Rotation Capacity of Aluminium Alloy Beams, Thin-Walled Structures, 27 (1997) 1 pp. 103-116
[21] Mennink, J., Soetens, F. \& Snijder, H.: Cross-sectional stability of aluminium extrusions with arbitrary cross-sectional shapesexperimental and numerical research, HERON, 50 (2005) 2, pp. 69-92

[22] Mennink, J.: Cross-sectional stability of aluminium extrusions (Doctoral thesis), University of Technology, Eindhoven, The Netherlands, 2002

[23] Kutanova, N., Peköz, T. \& Soetens, F.: Distortional elastic buckling for aluminium: Available prediction models versus design specifications, HERON, 55 (2010) 3/4, pp. 251-268

[24] De Matteis, G., Landolfo, R., Manganiello, M. \& Mazzolani, F. M.: Inelastic behaviour of I-shaped aluminium beams: numerical analysis and cross-sectional classification, Computers \& Structures, 82 (2004) 23-26, pp. 2157-2171

[25] Mazzolani, F. M. \& Mandara, A.: Inelastic Buckling Analysis of Aluminium Shells, Recent Advances and New Trends in Structural Design, Timisoara, Romania, 2004

[26] Manganiello, M., De Matteis, G. \& Landolfo, R.: Inelastic flexural strength of aluminium alloys structures, Engineering Structures, 28 (2006) 4, pp. 593-608

[27] Mazzolani, F. M., Mandara, A. \& Di Lauro, G.: Buckling of Aluminium Shells: Proposal for European Curves, International Conference on Thin Walled Structures, Loughborough, England, UK, 2004

[28] Mazzolani, F. M., Mandara, A. \& Di Lauro, G.: Remarks on the application of ENV1993-1-6: Buckling curves to aluminium shells, Nordic Steel Construction Conference, Copenhagen, Denmark, 2004.

[29] Mazzolani, F. M., Mandara, A. \& Di Lauro, G.: Plastic Buckling of Axially Loaded Aluminium Cylinders: A New Design Approach, Fourth International Conference on Coupled Instabilities in Metal Structures, Rome, Italy, 2004

[30] Qilin, Z., Hailin, T. \& Yage, W.: Effective section calculation of aluminium plate assemblies under uniform compression considering interactive local buckling, HERON, 55 (2010) 3/4, pp. 235-250

[31] van der Meulen, O., Maljaars, J. \& Soetens, F.: Cross-sectional classification of aluminium beams subjected to fire, HERON, 55 (2010) 3/4, pp. 285-302

[32] Maljaars, J.: Local buckling of slender aluminium sections exposed to fire (Doctoral thesis), University of Technology, Eindhoven, The Netherlands, 2008

[33] Hanssen, A. G., Hopperstad, O. S. \& Langseth, M.: Bending of square aluminium extrusions with aluminium foam filler, Acta Mechanica, 142 (2000) 1-4, pp. 13-31

[34] Wu, C., Zhao, X. L. \& Duan, W. H.: Design rules for web crippling of CFRP strengthened aluminium rectangular hollow sections, Thin-Walled Structures, 49 (2011) 10, pp. 1195-1207

[35] Zahurul Islam, S. M. \& Young, B.: Web crippling of aluminium tubular structural members strengthened by CFRP, Thin-Walled Structures, 59 (2012) 0, pp. 58-69

[36] Zhou, F. \& Young, B.: Concrete-filled aluminum circular hollow section column tests, Thin-Walled Structures, 47 (2009) 11, pp. 1272-1280

[37] Zhou, F. \& Young, B.: Tests of concrete-filled aluminum stub columns, Thin-Walled Structures, 46 (2008) 6, pp. 573-583

[38] American Iron and Steel Institure (AISI): AISI S100-2007, North American Specification for the Design of Cold-Formed Steel Structural Members, AISI, Washington DC, USA, 2007. 
[39] Australian/New Zealand Standard (AS/NZS): AS/NZS S4600:2005, Cold-formed steel structures, Standards Australia Limited/Standards New Zealand, Sydney, Australia, 2005.

[40] Zhou, F. \& Young, B.: Web crippling of aluminium tubes with perforated webs, Engineering Structures, 32 (2010) 5, pp. 13971410

[41] Hill, H. N., Hartmann, E. C. \& Clark, J. W.: Design of aluminum alloy beam-columns, Transactions of the American Society of Civil Engineers, 121 (1956) 1, pp. 1-14

[42] Klöppel,K.\&Bärsch,W.:Versuchezum Kapitel"Stabilitätsfälle"der Neufassung von DIN 4113, Aluminium, 49 (1973) 10, pp.

[43] Mazzolani, F. M.: Aluminium alloy structures, 2nd, Taylor \& Francis Ltd, London, United Kingdom, 1994.

[44] Structural Stability Research Council: Guide to stability design criteria for metal structures, 5th, John Wiley \& Sons, Inc., New York City, New York, USA, 1998.

[45] Zhu, J.-H. \& Young, B.: Aluminum alloy circular hollow section beam-columns, Thin-Walled Structures, 44 (2006) 2, pp. 131-140

[46] Zhu, J.-H. \& Young, B.: Experimental investigation of aluminum alloy circular hollow section columns, Engineering Structures, 28 (2006) 2, pp. 207-215

[47] Wang, Y. Q., Yuan, H. X., Shi, Y. J. \& Cheng, M.: Lateral-torsional buckling resistance of aluminium I-beams, Thin-Walled Structures, 50 (2012) 1, pp. 24-36

[48] Wu, Y. G. \& Zhang, Q. L.: Numerical and experimental study on flexural-torsional buckling coeffcient of aluminium beams, Journal of Building Structures, 27 (2006) 5, pp. 1-8

[49] Zhang, Z. \& Zhang, Q. L.: Experimental and theoretical research on in-plane stability capacity of $\mathrm{H}$-section aluminium beamcolumns, Journal of Building Structures, 27 (2006) 5, pp. 9-15

[50] Zhang, Z. \& Zhang, Q. L.: Experimental and theoretical research on lateral-torsional stability of $\mathrm{H}$-section aluminium beamcolumns, Journal of Building Structures, 40 (2010) 6, pp. 110-113

[51] Guo, X. N., Shen, Z. Y., Li, Y. Q., Su, C. \& Yao, N. L.: Theoretical and experimental research on aluminium alloy beams, Journal of Building Structures, 28 (2007) 6, pp. 129-135

[52] Edlund, S.: Buckling of T-Section Beam-Columns in Aluminium with or without Transverse Welds (Doctoral thesis), Royal Institute of Technology, Stockholm, Sweden, 2000.

[53] Zhu, J.-H. \& Young, B.: Numerical investigation and design of aluminum alloy circular hollow section columns, Thin-Walled Structures, 46 (2008) 12, pp. 1437-1449
[54] Soetens, F. \& van Hove, B.: Design of Connections Aluminium Structural Design, Springer-Verlag Wien New York, Udine, Italy, $187-252,2003$.

[55] Mathers, G.: The welding of aluminium and its alloys, Woodhead Publishing Limited, Cambridge, England, UK, 2002.

[56] Kissell, J. R. \& Ferry, R. L.: Aluminum structures: a guide to their specifications and design, Second, John Wiley \& Sons, Inc., New York City, New York, USA, 2002.

[57] The Aluminum Association (AA): Aluminum Design Manual, AA, Washington, District of Columbia, USA, 2005.

[58] European Committee for Standardization (CEN): EN 1999-1-1, Eurocode 9: Design of aluminium structures - Part 1-1: General structural rules, CEN, Brussels, Belgium, 2007.

[59] Han, L., Thornton, M., Boomer, D. \& Shergold, M.: A correlation study of mechanical strength of resistance spot welding of AA5754 aluminium alloy, Journal of Materials Processing Technology, 211 (2011) 3, pp. 513-521

[60] Cho, Y., Hu, S. \& Li, W.: Resistance spot welding of aluminium and steel: a comparative experimental study, Proceedings of the Institution of Mechanical Engineers, Part B: Journal of Engineering Manufacture, 217 (2003) 10, pp. 1355-1363

[61] Dørum, C., Lademo, O.-G., Myhr, O. R., Berstad, T. \& Hopperstad, O. S.: Finite element analysis of plastic failure in heat-affected zone of welded aluminium connections, Computers \& Structures, 88 (2010) 9-10, pp. 519-528

[62] Wang, T.: Modelling of Welded Thin-Walled Aluminium Structures (Doctoral thesis), Norwegian University of Science and Technology, Trondheim, Norway, 2006.

[63] Zhu, J.-H. \& Young, B.: Effects of transverse welds on aluminum alloy columns, Thin-Walled Structures, 45 (2007) 3, pp. 321-329

[64] De Matteis, G., Brando, G. \& Mazzolani, F. M.: Pure aluminium: An innovative material for structural applications in seismic engineering, Construction and Building Materials, 26 (2012) 1, pp. 677-686

[65] Ratković, N., Sedmak, A., Jovanović, M., Lazić, V., Nikolić, R. \& Krstić, B.: Quality analysis of Al-Cu joint realized by friction welding, Technical Gazette, 16 (2009) 3, pp. 3-7

[66] Kahl, S.: The influence of small voids on the fatigue strength of friction stir welds in the aluminium alloy AA6061-T6, HERON, 55 (2010) 3/4, pp. 223-234 